\title{
Grit toward Career Development: A Study among Technical Instructors in Malaysia
}

\author{
Badaruddin Ibrahim, Nurul Haerani Mohamad, Azlihan Bin Abd Aziz, Mahadi Bin Kadir, \\ Zulisham Bin Abd Hamid
}

\begin{abstract}
Grit describes an individual's tendency for passion and perseverance towards long-term goals and has been established as an indicator of achievement beyond talent and intelligence. A widely recognized belief is that indicators of professional and academic success extend beyond cognitive intelligence; for example, we know, anecdotally, that hard work and effort pay off. It has been established that any area of industries including teaching and learning requires the hard work of learning and practice for exacting a good result on teachers and students performances, making the need for perseverance necessary. This study quantitatively examined the relationship between grit and career development of technical instructors in Malaysia based on age, education level and years of services. The data for this research were obtained through structured questionnaire and involved 88 technical instructors from Malaysia Technical Institute. The study findings identified that grit: the power of passion and perseverance related to long lasting career development. More broadly, this study provides a qualitative and dimensional understanding of the phenomena of grit as related to career development.
\end{abstract}

\section{Keywords: Grit, Career Development, Technical Instructor}

\section{INTRODUCTION}

A successful, engaging, and satisfying career has numerous positive outcomes for both employer and employee [1] [2] [3]. Careers provide people with meaning and identity [4] and career success is strongly related to overall life satisfaction [5]. Life satisfaction is key to attaining psychological well-being [6]. Attaining career development and success has a number of positive outcomes such as mental and physical health [7] at the other end of the spectrum, career failure may result in hopelessness, depression, and even suicide [8]. In career development, well-being can be examined within the work environment, because work satisfaction is a key component to well-being [9].

Recent years have seen a heightened interest on grit as predictor for success in career development. Grit has defined as "perseverance and passion for long-term goals", and they posit that these variables contribute to success in individuals [10]. Past research on understanding core traits of successful

Revised Manuscript Received on April 19, 2019.

Badaruddin Ibrahim, Faculty of Technical \& Vocational Education, Universiti Tun Hussein Onn Malaysia, Batu Pahat, Johor, Malaysia

Nurul Haerani Mohamad, Faculty of Technical \& Vocational Education, Universiti Tun Hussein Onn Malaysia, Batu Pahat, Johor, Malaysia

Azlihan Bin Abd Aziz, Majlis Amanah Rakyat (MARA), Kuala Lumpur, Malaysia

Mahadi Bin Kadir, Majlis Amanah Rakyat (MARA), Kuala Lumpur, Malaysia

Zulisham Bin Abd Hamid, Majlis Amanah Rakyat (MARA), Kuala Lumpur, Malaysia individuals has been explored [11] [12]. In economics, management, and psychology, research has explored cognitive ability and personality traits as "powerful predictor of economic outcomes" [13].

Studies on success in careers development point to a combination of innate natural talent and effort. Authors [14] emphasize that being successful and thriving "can be defined either objectively or subjectively. Objective success entails doing well according to some common metric uniformly applied to all individuals in a society, whereas subjective success concerns an individual's personal assessment of his or her life situation". Education also underpins the process of innovative and highly skilled human capital development which is a critical factor in supporting the social, cultural and economic growth of a country [15]. As such, the Malaysian government has worked hard to realize the wish through the fourth shift Malaysia's Education Blueprint 2013-2025 which transforms the teaching into an optional profession. The improvement of teachers' professionalism and quality should be prioritized to achieve Malaysia's Education Blueprint 2013-2025 goals 2013-2025. Grit can be an important factor in explaining the achievement and persistence in maintaining the expected quality of teacher performance [16]. Therefore this study quantitatively examined the relationship between grit and career development of technical teacher in Malaysia based on age, education level and years of services.

\section{LITERATURE REVIEW}

\section{Grit as a Predictor of Success in Career Development}

Proponents of grit as a predictor of performance toward success in career development have argued that betweenperson differences in grit can help to explain why two individuals with the same level of ability in a particular domain are often observed to perform at substantially different levels. Specifically individuals with high levels of grit are thought to be able to better utilize their capabilities because they are less distracted by short-term goals and less discouraged by the failures and setbacks that are commonly encountered in many performance domains. Indeed, the importance of grit for success had long been noted by prior research into highly accomplished individuals [10] [17] Arguments for the importance of grit are also in line with work on the development of expertise that has highlighted 
the importance of sustained deliberative practice [18] [19]. Indeed, recent work by authors [14] has explicitly tied grit to success in spelling bees via the mediating mechanism of deliberative practice. That is, individuals who are high on grit are more likely to engage in the amount of deliberative practice that is required to achieve expertise.

Author [11] observed that, in terms of attitude towards one's own qualities, people could either have a fixed mindset (belief that one's qualities are inborn and fixed) or a growth mindset (one can improve over time). Successful people have a growth mindset and they never stop exploring and improving. Passion and perseverance in attaining longterm goals are essential elements of grit [14] [20] [21]. Individuals with high levels of grit may exhibit a drive stronger than the average person. For high achievers, the extra push that passion and flow provide are essential, no matter what field one may choose to specialize in. Positive affect results from performance of a task especially when accompanied by passion, flow, or a "high" in short bursts. However, it takes more will to persevere and persist when faced with great odds.

\section{Recent Study on Grit}

To measure grit, [14] developed and validated a selfreport questionnaire based on the construct definition of grit as described above. The scale was intended to be used for adolescents and adults who pursue goals in a variety of domains, thus as a domain-general measure (e.g., not just work or school). On these grounds, the authors selected and piloted items for their measure in the US, resulting in the 12-Item Grit Scale. They identified a two-factor structure for the scale. The model fit for a two-factor solution suggested room for improvement, but the scale showed high internal consistency and predictive validity for a variety of success outcomes. In a subsequent validation study, [22] revisited the issue of model fit. The model fit improved substantially when two items were removed from each subscale, leaving eight items in total. The resulting 8-Item scale was named the Short Grit Scale (Grit-S). A second-order factor was included in the model, representing the superordinate latent construct grit. Even though they found differential associations with predicted outcomes for the two subscales, their pattern of findings supports the conceptualization of grit as a compound trait. To our knowledge, only few studies have been published on grit in a Malaysia context so far [23] [24] and a validation study for measures of grit in Malaysia do not exist. Therefore, this study takes a place to fulfill the gap.

\section{Social Cognitive Career Theory}

Social cognitive career theory was used to frame the career success element of this study. Social cognitive career theory was developed in order to integrate various career theories with social cognitive theory [25]. Within the realm of counseling psychology, well-being is considered changeable [26]. It is possible, therefore, to consider that change in levels of well-being may occur through working toward an engaging and satisfying career and by flourishing in one's career. Social cognitive career theory was developed to address developmental changes in both educational and vocational settings [27].

In career development, well-being can be examined within the work environment, because work satisfaction is a key component to well-being [28]. Social cognitive career theory intends to predict how people make career choices and also how they achieve varying levels of success in their jobs [16]. The rationale for meshing social cognitive theory with career theories was to apply the influences of cognitive, personal, and environmental elements with a holistic approach to career development that included diverse influences and central pathways by which they impacted career behavior [25]. Social cognitive career theory focuses on the level of success people attain in their work and how well they persevere at a specific career path despite obstacles [29] [30]. Because grit is defined as passion and perseverance in working toward long-term goals despite setbacks [10] and these elements are cognitive, social cognitive career theory was an especially strong choice for examining the relationship between grit and career success

\section{METHODOLOGY}

The purpose of this study was describe grittiness of technical instructors in Malaysia from Malaysian public technical institutions and determine if grit is associated with successful career development based on age, education level and years of services. The sample consisted of $\mathrm{N}=88$ technical instructors at public Malaysia Technical Institution under Rural Development Ministry. The data were obtained through the distribution of questionnaires adapted from 'Short Grit Scale, Grit-S' [32]. In accordance with the original version, a 5-point Likert scale was chosen as the response format for the Malay version of the Grit-S (1 = very much like me to $5=$ not at all like me). The Grit-S instrument demonstrated acceptable reliability in our sample with Cronbach's alpha of .67 (See Table 1).

Table 1: Reliability Statistic of Grit-Score (Grit-S)

\begin{tabular}{ll}
\hline Cronbach's Alpha & N of Items \\
\hline .67 & 8 \\
\hline
\end{tabular}

The purpose of this instrument was to measure an individual's grittiness. The Grit-S scale is a shorter version of the original validated instrument, used to determine an individual's grittiness [32]. The instrument was developed as a valid and reliable assessment in order to measure an individual's self-report of grit [10]. The instrument has been used in numerous studies [31] [32] [33].

The Grit-S consists of eight questions. The instrument utilizes a five-point Likert scale that includes a range of five responses: very much like me, mostly like me, somewhat like me, not much like me, and not like me at all. Questions 2, 4, 7, and 8 measure the sub score perseverance of effort, which was developed from the original Big Five Inventory to measure an individual's will to continue toward a goal [35]. Questions 1, 3, 5, and 6 measure the sub score consistency of interest, which was also developed from the Big Five Inventory to measure an individual's will to continue toward a goal for the long term. Table 2 shows the detail of the instrument. 
Table 2: Grit-S Subscales and Scoring

\begin{tabular}{|c|c|c|}
\hline Items & $\begin{array}{r}\text { Response } \\
\text { and Scoring }\end{array}$ & Option \\
\hline $\begin{array}{l}\text { Consistency } \\
\text { Interest }\end{array}$ & & \\
\hline \begin{tabular}{ll}
\multicolumn{1}{c}{$1-$ New } & ideas and \\
projects & sometimes \\
distract me from \\
previous ones.
\end{tabular} & & \\
\hline
\end{tabular}

3- I have been obsessed with a certain idea or project for a short time but later lost interest.

5- I often set a goal but later choose to pursue a different one.*

6- I have difficulty maintaining my focus on projects that take more than a few months to complete.*

\begin{tabular}{|c|c|}
\hline $\begin{array}{l}\text { Perseverance } \\
\text { Effort }\end{array}$ & \\
\hline $\begin{array}{l}\text { 2- Setbacks don't } \\
\text { discourage me. }\end{array}$ & $\begin{array}{c}5=\text { Very much like } \\
\text { me; 4=Mostly like me; }\end{array}$ \\
\hline $\begin{array}{c}\begin{array}{c}\text { 4- } \\
\text { worker. }\end{array} \\
\text { I }\end{array}$ & $\begin{array}{l}3=\text { Somewhat like me; } \\
2=\text { Not Much like me; }\end{array}$ \\
\hline $\begin{array}{l}\text { 7- I finish whatever I } \\
\text { begin. }\end{array}$ & $1=$ Not like me at all \\
\hline 8-I am diligent. & \\
\hline
\end{tabular}

The highest possible combined overall score on the Grit-S is 5. The instrument is scored by collecting the initial highest possible score (between 8 and 40 points) and dividing it by the total number of questions, which is eight [34]. For this study's purpose, "grittiest" refers to those participants whose grit score falls within the 70th percentile and above according to data drawn from Duckworth's analysis of a large sample of adult Americans; "less gritty" refers to those who fall below the 70th percentile (See Table 3)

Table 3: Percentile Grit Scores of Large Sample of American Adults [33]

\begin{tabular}{ll}
\hline Percentile & Grit Score \\
\hline $10 \%$ & 2.5 \\
\hline $20 \%$ & 30 \\
\hline $30 \%$ & 3.3 \\
\hline $40 \%$ & 3.5 \\
\hline $50 \%$ & 3.8 \\
\hline $60 \%$ & 3.9 \\
\hline $70 \%$ & 4.1 \\
\hline $80 \%$ & 4.3 \\
\hline $90 \%$ & 4.5 \\
\hline $95 \%$ & 4.7 \\
\hline $99 \%$ & 4.9 \\
\hline
\end{tabular}

The administration of the questionnaire took approximately $15 \mathrm{~min}$. The data were analyzed using the
PSPPIRE software based on descriptive and inferential analysis procedures.

\section{RESULTS AND FINDINGS}

\section{Sample characteristics}

In this sample, $82.95 \%(\mathrm{n}=73)$ of participants were male, and $15 \%(\mathrm{n}=15)$ were female. The average age of participants was $31-40(54.55 \%)$. Mostly participants was diploma holders, 50.00\%, $(\mathrm{n}=44)$. Only $2.27 \%(\mathrm{n}=2)$ participant having Malaysia Skills Certificate (SKM). The sample was primarily from position of Asst. Vocational Training Officer 69.32\%, $(n=61)$, and Vocational Training Officer was $30.68 \%, \mathrm{n}=27$ ). The average year of services participant had been working was 11-15 (38.64\%). See Table 4 for demographic information about this sample.

Table 4: Demographic Characteristics of Sample $(\mathbf{N}=\mathbf{8 8})$

\begin{tabular}{|c|c|c|}
\hline Characteristic & $\begin{array}{l}\text { Sample } \\
\text { (n) }\end{array}$ & $\begin{array}{l}\text { Percent } \\
(\%)\end{array}$ \\
\hline \multicolumn{3}{|l|}{ Gender } \\
\hline Male & 73 & 82.95 \\
\hline Female & 15 & 17.05 \\
\hline \multicolumn{3}{|l|}{ Age } \\
\hline 20-30 years old & 2 & 1.14 \\
\hline $31-40$ years old & 48 & 54.55 \\
\hline 41-50 years old & 29 & 34.09 \\
\hline 51-60 years old & 9 & 10.23 \\
\hline \multicolumn{3}{|l|}{ Education Level } \\
\hline Master & 8 & 9.09 \\
\hline Degree & 29 & 32.95 \\
\hline Diploma & 44 & 50.00 \\
\hline SPM & 3 & 3.41 \\
\hline Certificate & 2 & 2.27 \\
\hline SKM & 2 & 2.27 \\
\hline \multicolumn{3}{|l|}{ Position } \\
\hline $\begin{array}{l}\text { Asst. Vocational } \\
\text { Training Officer }\end{array}$ & 61 & 69.32 \\
\hline $\begin{array}{ll}\text { Vocational } & \text { Training } \\
\text { Officer } & \\
\end{array}$ & 27 & 30.68 \\
\hline \multicolumn{3}{|l|}{ Years of Services } \\
\hline$<5$ years & 5 & 5.68 \\
\hline $6-10$ years & 13 & 14.77 \\
\hline $11-15$ years & 34 & 38.64 \\
\hline 16-20 years & 19 & 21.64 \\
\hline $21-25$ years & 12 & 13.64 \\
\hline$>26$ years & 5 & 5.68 \\
\hline
\end{tabular}

\section{Grit Score (Grit-S) of Participant}

For this study's purpose, "grittiest" refers to those participants whose grit score falls within the 70th percentile and above according to data drawn from Duckworth's analysis of a large sample of adult Americans; "less gritty" refers to those who fall below the 70th percentile. The participants grit scores ranged from 2.25 to 4.9 out of 5.000

Published By: 
with $\mathrm{M}$ of $3.68, \mathrm{SD}=0.91$. Researchers used a comparative measure to determine the participants to be an overall "gritty population" and categorize the participants into groups of "gritty" and "less gritty." Table 5, below, compares the range of the 88 participant's grit scores to the percentage of the large adult population sample in Table 3.

Table 6 shows that only $18(17.05 \%)$ out of 88 of the participants have a grit score of 4.1 or higher, $70 \%$ scoring above the adult sample population, confirming the assumption that this is clearly a less gritty population.

Table 5: Percentile of Grit Scores of Participant as

Compared to Large Sample of American Adults

\begin{tabular}{|c|c|c|c|c|c|}
\hline $\begin{array}{l}\text { Adult } \\
\text { Sampl } \\
\text { e } \\
\text { Percen } \\
\text { tile }\end{array}$ & $\begin{array}{l}\text { Grit } \\
\text { Score }\end{array}$ & $\begin{array}{l}\text { Parti } \\
\text { cipan } \\
\text { ts } \\
\text { Grit } \\
\text { Score }\end{array}$ & $\begin{array}{l}\text { Total } \\
\text { Parti } \\
\text { cipan } \\
\text { ts }\end{array}$ & $\begin{array}{l}\% \\
\text { Parti } \\
\text { cipan } \\
\text { ts }\end{array}$ & $\begin{array}{l}\text { Operat } \\
\text { ional } \\
\text { Definit } \\
\text { ion }\end{array}$ \\
\hline \multirow[t]{2}{*}{$99 \%$} & 4.9 & 2 & \multirow[t]{7}{*}{18} & \multirow{7}{*}{$\begin{array}{l}17.05 \\
\%\end{array}$} & \multirow{7}{*}{$\begin{array}{l}\text { Gritties } \\
\mathrm{t}\end{array}$} \\
\hline & 4.8 & 0 & & & \\
\hline $95 \%$ & 4.7 & 1 & & & \\
\hline \multirow[t]{2}{*}{$90 \%$} & 4.5 & 2 & & & \\
\hline & 4.4 & 5 & & & \\
\hline $80 \%$ & 4.3 & 3 & & & \\
\hline \multirow{2}{*}{$70 \%$} & 4.1 & 5 & & & \\
\hline & 4.0 & 6 & \multirow[t]{11}{*}{70} & \multirow{11}{*}{$\begin{array}{l}82.95 \\
\%\end{array}$} & \multirow{11}{*}{$\begin{array}{l}\text { Less } \\
\text { Gritty }\end{array}$} \\
\hline $60 \%$ & 3.9 & 9 & & & \\
\hline \multirow[t]{2}{*}{$50 \%$} & 3.8 & 10 & & & \\
\hline & 3.6 & 10 & & & \\
\hline \multirow[t]{2}{*}{$40 \%$} & 3.5 & 12 & & & \\
\hline & 3.4 & 2 & & & \\
\hline $30 \%$ & 3.3 & 8 & & & \\
\hline \multirow[t]{3}{*}{$20 \%$} & 3.0 & 9 & & & \\
\hline & 2.8 & 1 & & & \\
\hline & 2.6 & 1 & & & \\
\hline $10 \%$ & 2.5 & 2 & & & \\
\hline $\begin{array}{l}\text { Total } \\
\text { Partici }\end{array}$ & & 88 & & & \\
\hline
\end{tabular}

Table 6: Summary of Range of Participants' Grit as Compared to Adult Sample Percentile

\begin{tabular}{llll}
\hline $\begin{array}{l}\text { Grit-S } \\
\text { Score }\end{array}$ & Participants & $\begin{array}{l}\text { \% } \\
\text { Participants }\end{array}$ & Percentile \\
\hline $4.1-4.9$ & 18 & $17.05 \%$ & $\begin{array}{l}70 \text { and } \\
\text { above }\end{array}$ \\
\hline $2.5-4.0$ & 70 & $82.95 \%$ & 20 to 70 \\
\hline Total & 88 & $100 \%$ & - \\
\hline
\end{tabular}

Correlation between Grit and Successful Career Development

To confirm the conclusion drawn from previous data, researchers conducted Pearson's $r$ correlation analyses between the predictor and each outcome variable for the Grit-S and the career development variables (age, education level and years of services). See Table 7 below for Pearson's $r$ results. The results of the Pearson's correlation analyses were contrary to the predicted relationship based on past research that indicated a relationship between grit and successful career development factors (age, education level and years of services).
Correlation Coefficients were computed among the variables as shown in Table 7. The result shows that low correlation between Grit-S and career development variables of age $(\mathrm{r}=-.12, \mathrm{p}=0.268>0.05)$. Next, a negative significant correlation also found between Grit-S and career development variables of education level $(\mathrm{r}=-.14, \mathrm{p}=0$. $192>0.05)$. Grit-S and career development variables of years of services $(r=-.13, p=0.237>0.05)$ consistently shows low correlation.

Overall, results indicated that this sample have low levels of grit and career success. The average Grit-S score was 3.5 and there were also the correlation analyses demonstrated that grit did not show a positive correlation with career success.

Table 7: Correlation between Grit-S and Age

\begin{tabular}{|c|c|c|c|}
\hline & & AGE & $\begin{array}{l}\text { Grit- } \\
\text { Score } \\
\text { (Grit-S) }\end{array}$ \\
\hline \multirow{3}{*}{ Age } & $\begin{array}{l}\text { Pearson } \\
\text { Correlation }\end{array}$ & 1.00 & -.12 \\
\hline & $\begin{array}{l}\text { Sig. } \\
\text { tailed) }\end{array}$ & & .268 \\
\hline & $N$ & 88 & 88 \\
\hline \multirow{4}{*}{$\begin{array}{l}\text { Grit-Score } \\
\text { (Grit-S) }\end{array}$} & $\begin{array}{l}\text { Pearson } \\
\text { Correlation }\end{array}$ & -.12 & 1.00 \\
\hline & $\begin{array}{l}\text { Sig. } \\
\text { tailed) }\end{array}$ & 2.68 & \\
\hline & $N$ & 88 & 88 \\
\hline & & $\begin{array}{l}\text { Education } \\
\text { Level }\end{array}$ & $\begin{array}{l}\text { Grit- } \\
\text { Score } \\
\text { (Grit-S) }\end{array}$ \\
\hline \multirow{3}{*}{$\begin{array}{l}\text { Education } \\
\text { Level }\end{array}$} & $\begin{array}{l}\text { Pearson } \\
\text { Correlation }\end{array}$ & 1.00 & -.14 \\
\hline & $\begin{array}{l}\text { Sig. } \\
\text { tailed })\end{array}$ & & .192 \\
\hline & $N$ & 88 & 88 \\
\hline \multirow{4}{*}{$\begin{array}{l}\text { Grit-Score } \\
\text { (Grit-S) }\end{array}$} & $\begin{array}{l}\text { Pearson } \\
\text { Correlation }\end{array}$ & -.14 & 1.00 \\
\hline & $\begin{array}{l}\text { Sig. } \\
\text { tailed) }\end{array}$ & .192 & \\
\hline & $N$ & 88 & 88 \\
\hline & & $\begin{array}{l}\text { Years of } \\
\text { Services }\end{array}$ & $\begin{array}{l}\text { Grit- } \\
\text { Score } \\
\text { (Grit-S) }\end{array}$ \\
\hline \multirow{3}{*}{$\begin{array}{ll}\text { Years of } \\
\text { Services }\end{array}$} & $\begin{array}{l}\text { Pearson } \\
\text { Correlation }\end{array}$ & 1.00 & -.13 \\
\hline & $\begin{array}{l}\begin{array}{l}\text { Sig. } \\
\text { tailed })\end{array} \\
\end{array}$ & & .237 \\
\hline & $N$ & 88 & 88 \\
\hline \multirow[t]{3}{*}{$\begin{array}{l}\text { Grit-Score } \\
\text { (Grit-S) }\end{array}$} & $\begin{array}{l}\text { Pearson } \\
\text { Correlation }\end{array}$ & -.13 & 1.00 \\
\hline & $\begin{array}{l}\text { Sig. } \\
\text { tailed })\end{array}$ & 2.37 & \\
\hline & $N$ & 88 & 88 \\
\hline
\end{tabular}




\section{DISCUSSION AND CONCLUSION}

The In sum, this study presents that grit didn't encourages Malaysian technical instructors to determine their success in career development. There was no significant relationship found between grit and career development variables (age, education level and years of services). In previous studies, grit only explained a very small amount of total variance explained when age, education level and years of services were accounted for [10] or did not significantly predict Malaysia technical instructors successful in career development. Further, authors [36] found that grit varied with age. Therefore, it is likely that grit doesn't provide enough discriminant power among Malaysia technical instructors, perhaps because their interests are not stable yet and the benefits of persistent effort had not yet made themselves readily apparent. From an evolutionary perspective, novelty seeking behavior can be considered adaptive among young adults, who many are still trying to discover what they are good at and what they enjoy doing. Hence, grit may have better postdictive power especially among older populations. This can be seen in terms of those who have served for 15 years and have low percentage value compared to those who work for 10 to 13 years. Authors [37] [38] justified that those who have long served is no longer interested or do not want to be burdened with problems at work. They just want to focus fully on families as well as waiting for retirement.

In terms of education level factor, most of technical instructors are graduating from diploma and are motivated to increase their career level. This is because the percentage shows those who are diploma holders have a high percentage and are encouraged to improve their careers. Their interest is also one of the driving factors for their career development. Compared with Master holder, the data shows the lowest percentage for them to improve their careers. Thus, it can be seen that the level of education also affects grit for the purpose of their career development. Therefore, each individual has its own grit whether consciously or not in determining the development of their respective successful career development.

There are limitations to this research and hope for future research direction. Grit dimensions discussed thus far in the literature are certainly not exhaustive. Moreover, with the nature of research samples utilized, findings may not be applicable to other cases and could not serve as bases for generalization. Future research may be done into the main ideas that emerged from this research. Examining individual characteristics, organizational accounts, as well as work performance and their corresponding relationship to grit, can lead to refinement of the conceptualization of grit in a nonWestern setting. Both studies are exploratory in nature. The findings show important aspects to consider such as the conceptualization of social support in Asia and its links to grit and success and superior performance in a corporate setting.

The paper has built on existing research on grit and has shown new ways of seeing grit in a specific non-Western setting. The availability of potential research areas and the need for new approaches - both conceptual and empirical to study grit are important considerations. It is the authors ${ }^{\text {ec }}$ hope that, as the discussion and studies on grit continue and conceptualizations become clearer, the different dimensions of grit related to work performance and successful career development would provide a better understanding of the concept.

\section{CONCLUSION}

A conclusion section is not required. Although a conclusion may review the main points of the paper, do not replicate the abstract as the conclusion. A conclusion might elaborate on the importance of the work or suggest applications and extensions.

\section{ACKNOWLEDGMENT}

The authors would like to thank Ministry of Education Malaysia MOE) for funding this research. The support given by MOE under "Geran Pensiswazahan Guru" (PPG) Vote No K025 for providing the facilities to perform this research is highly appreciated.

\section{REFERENCES}

1. Parasuraman, S., Purohit, Y. S., \& Godshalk, V. M., "Work and family variables, entrepreneurial career success, and psychological well-being". Journal of Vocational Behavior, June,1996, 48, 275-300.

2. Robertson, I., \& Cooper, C., "Well-being: Productivity and happiness at work". Hampshire, UK: Palgrave Macmillan, 2011.

3. Wiese, B. S., Freund, A. M., \& Baltes, P. B., "Subjective career success and emotional well-being: Longitudinal predictive power of selection, optimization, and compensation", Journal of Vocational Behavior,2002, 60(3), 321-335

4. Forest, J., Mageau, G. A., Sarrazin, C., \& Morin, E. M., "Work is my passion": The different affective, behavioral, and cognitive consequences of harmonious and obsessive passion toward work". Canadian Journal of Administrative Sciences, 2011, 28(1), 27-40.

5. Erdogan, B., Bauer, T. N., Truxillo, D. M., \& Mansfield, L. R., "Whistle while you work: A review of the life satisfaction literature". Journal of Management, 2012, 38(4), 1038-1083.

6. Diener, E., \& Tov, W., "Well-being on planet Earth. Psychological Topics", 2009, 18(2), 213-219.

7. Russo, M., Guo, L., \& Baruch, Y. "Work attitudes, career success and health: Evidence from China". Journal of Vocational Behavior, 2014, 84(3), 248-258.

8. Duff, A. J., \& Chan, C. C., "Investigating suicide as a career response". Career Development International, 2014, 19(1), 4-26.

9. Heller, D., Watson, D., \& Remus, I., "The role of person versus situation in life satisfaction: A critical examination. Psychological Bulletin, 2004, 130(4), 574 600.

10. Duckworth, A.L., Peterson, C., Matthews, M., \& Kelly, D. (2007, October). Grit: Perseverance and passion for long-term goals. Journal of Personality and Social Psychology, 92(6), 1087- 1101. Available: https://psycnet.apa.org/journals/psp/92/6/1087/

11. Dweck, C., "Mindset: The New Psychology of Success". New York: Ballantine Books, 2007.

12. Borghans, L. A. Duckworth, J. Heckman and B. Weel.,
Blue Eyes Intelligence Engineering

\& Sciences Publication 
"The Economics and Psychology of Personality Traits". The Journal of Human Resources, 2008, 43(4), pp. 9721059.

13. Fergurson, M., L. Hitt and P. Tambe., "The Talent Equation: Big Data Lessons for Navigating the Skills Gap and Building a Competitive Workforce”. New York: McGraw-Hill, 2014.

14. Duckworth, A.L., Kirby, T., Tsukayama, E., Berstein, H., \& Ericsson, K., "Deliberate practice spells success: Why grittier competitors triumph at the National Spelling Bee". Social Psychological and Personality Science, 2011, 2(2), 174-181.

15. Bujang, Z. \& Yusof, Y. Z., "Trait Personaliti Dan Hubungan Dengan Prestasi Akademik Bakal Guru Di Sesebuah Institusi Latihan Perguruan". Jurnal Bitara

16. Bowman, N. A., Hill, P. L., Denson, N., \& Bronkema, R. (2015, March), 'Keep on truckin' or stay the course? Exploring grit dimensions as differential predictors of educational achievement, satisfaction, and intentions". Social Psychology and Personality Science, 6(6), 639654.

Available: https://journals.sagepub.com/doi/abs/10.1177/194855061 $\underline{5574300}$

17. Howe, M. J. A., "Genius explained". New York: Cambridge University Press, 1999.

18. Ericsson, K. A., Krampe, R. T., \& Tesch-Römer, C., "The role of deliberate practice in the acquisition of expert performance". Psychological Review, 1993, 100 , 363-406. Available: doi:10.1037/0033-295X.100.3.363

19. Krampe, R. T., \& Ericsson, K. A., "Maintaining excellence: Deliberate practice and elite performance in young and older pianists". Journal of Experimental Psychology: General, 1996, 125, 331-359. Available: https://psycnet.apa.org/record/1996-06578-001

20. Duckworth, A.L., Quinn, P. D., \& Seligman, M. E. P. (2009, June), "Positive predictors of teacher effectiveness". The Journal of Positive Psychology, 4(6), 540-547.

Available: https://www.tandfonline.com/doi/abs/10.1080/17439760 903157232

21. Robertson-Kraft, C., \& Duckworth, A. (2014, January), "True grit: Trait-level perseverance and passion for longterm goals predicts effectiveness and retention among novice teachers". Teachers College Record, 116(3), 1-27. Available:

https://www.ncbi.nlm.nih.gov/pmc/articles/PMC4211426 I

22. Duckworth, A.L., \& Quinn, P. D., "Development and validation of the Short Grit Scale (Grit-S)". Journal of Personality Assessment, 2009, 91(2), 166-174.

23. Ramasamy, S., \& Mun, Y. S., "Mediating effect of utilisation of emotion on the relationship between grit and psychological contract”. Jurnal Psikologi Malaysia, 2017, 31(3)

24. Kiat, G. B., "Research on grit: The important of grit towards an entrepreneur long term succession in Melaka, Malaysia" (Bachelor Dissertation, University Teknikal Melaka), 2016.

25. Lent, R., Brown, S., \& Hackett, G. (1994, August), "Toward a unifying social cognitive theory of career and academic interest, choice, and performance". Journal of Vocational Behavior, 45(1), 79-122. Available: https://www.sciencedirect.com/science/article/abs/pii/S0 $00187918471027 \mathrm{X}$

26. Lent, R., \& Brown, S. (2008, February), "Social cognitive theory and subjective well-being in the context of work". Journal of Career Assessment, 16(6), 6-21. Available:

https://journals.sagepub.com/doi/abs/10.1177/106907270 $\underline{7305769}$ Edisi Khas (Psikologi Kaunseling), 2008, Vol.8, 171-180.

27. Lent, R., \& Brown, S., "Social cognitive model of career self-management: Toward a unifying view of adaptive career behavior across the life span". Journal of Counseling Psychology, 2013, 60(4), 557-568. Available : https://psycnet.apa.org/record/2013-23511-001

28. Heller, D., Watson, D., \& Remus, I., "The role of person versus situation in life satisfaction: A critical examination". Psychological Bulletin, 2004, 130(4), 574600.

29. Lent, R. W., \& Brown, S. D., "Social cognitive approach to career development: An overview". Career Development Quarterly, 1994, 44(4), 310-321.

30. Ahmad, H., \& Ibrahim, B. (2015), "Exploration of Leadership in Technical, Vocational, Education and Training, Lesson to be Learned". Advanced Science Letters, 21(6), 2169-2171

31. Sumarwati, S., Yunos, J. M., \& Ibrahim, B. (2017), "Transferable skills for $\mathrm{Ph}$. D. students to finish the journey”. Advanced Science Letters, 23(2), 968-971.

32. Duckworth, A. L., \& Quinn, P. D. (2009, October), "Development and validation of the Short Grit Scale (GRIT-S)". Journal of personality assessment, 91(2), 166-174. Available: https://doi.org/10.1080/00223890802634290

33. Datu, J. A. D., \& Valdez, J. P. M., "Psychological capital predicts academic engagement and well-being in Filipino high school students". The Asia-Pacific Education Researcher, 2016, 25(3), 399-405.

34. Wolters, C. A., \& Hussain, M., "Investigating grit and its relations with college students' self-regulated learning and academic achievement". Metacognition and Learning, 2015, 10(3), 293-311.

35. Duckworth, A., \& Duckworth, A., "Grit: The power of passion and perseverance" (Vol. 234). New York, NY: Scribner, 2016, July.

36. Duckworth, A.L., \& Gross, J. J. (2014, October), "Selfcontrol and grit: Related but separable determinants of success". Current Directions in Psychological Science, 23(5), 319-325. Available https://journals.sagepub.com/doi/abs/10.1177/096372141 4541462

37. Hill, P. L., Burrow, A. L., \& Bronk, K. C.,(2016, February), "Persevering with positivity and purpose: An examination of purpose commitment and positive affect as predictors of grit". Journal of Happiness Studies, 2016, 17(1), 257-269. Available: https://link.springer.com/article/10.1007/s10902-0149593-5

38. Mohamad, N. H. \& Selamat, A., "Exploration of spiritual elements in holistic entrepreneur (holistic-e): student development perspectives". International Journal of Engineering \& Technology, 2018, 7 (3.30), 82-86

\section{AUTHORS PROFILE}

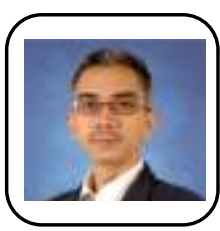

Associate Profesor Dr. Badaruddin Ibrahim received his early education in Selangor and Kuala Lumpur before pursuing his study in Bachelor Degree in Mechanical Engineering at Universiti Teknologi Malaysia, Johor. He did his Ph.D. in Education and Human Resource Studies at Colorado State University, USA. Currently, Associate Profesor Dr. Badaruddin Ibrahim is a Deputy Dean (Research, Development \& Publication) at Faculty of Technical and Vocational Education (FPTV), UTHM since 2013. His expert area is in Test and Measurement in STEM Education and TVET. His current research "Engineering Design Assessment Instrument for Student's Design Project based on Industrial Revolution 4.0." funded by the UTHM. He also involve 
in product development project through student final year project. He has experience in research collaboration especially within the ASEAN countries through FPTV membership in Southeast Asian Ministers of Education Organization Regional Centre for Vocational and Technical Education and Training (SEAMEO VOCTECH) and Regional Association for Vocational Teacher Education in East Southeast Asia (RAVTE). He has been appointed as External Advisory Panels (Academic) at UNISEL from April 2018 until March 2020

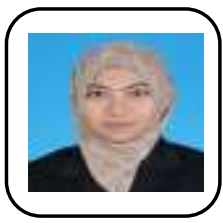

Nurul Haerani Binti Mohamad, received a Bachelor in Technology Management (Production and Operation) and finished her Master in Technical and Vocational Education at Universiti Tun Hussein Onn Malaysia (UTHM). Currently, she is pursuing her Doctor of Philosophy in Technical and Vocational Education at the same university. She is now a research assistant, editor and part-time lecturer. Her expert area is in holistic student development, co-curriculum, and entrepreneurship

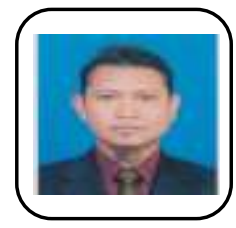

Azlihan Bin Abd Aziz received a Bachelor of Electrical Engineering degree with honors at Universiti Tun Hussein Onn, Malaysia (UTHM), Higher National Diploma (HND) in Electrical and Electronic (British Malaysian Institute) and Diploma in Skills Malaysia (Department of Skills Development). He is also a member of the Board of Engineer Malaysia (BEM) and Malaysia Board of Technologists (MBOT). He has a Vocational Training Certificate (VTO) approval by Advanced Training and Skills Training Center (CIAST) and he is directly involved with Malaysian Skill Certificate (SKM) as Appraisal Officer, Internal Assessment Officer and External Evaluation Officers. He experienced as inspector panel for Certificate of Competency Energy Commission (ST) Electric Car Guard (Chargeman) category AO, A1 and A4. Before joining Majlis Amanah Rakyat (MARA), he worked at several industrial companies such as Hitachi Display Devices (M) Sdn Bhd, Brother Industries Johor (M) Sdn Bhd, Sony Display Devices Singapore Ptd Ltd and NH. Techno Glass Singapore Ptd Ltd. Currently, he was a lecturer at Majlis Amanah Rakyat (MARA) from 2001 till present and experienced in teaching A1 Certificate of Electrical Engineering Technology (Power) A1, Diploma of Electrical Compensation (A4 Machinery Guardian) and Diploma in Technology Engineering (Domestic and Industrial).

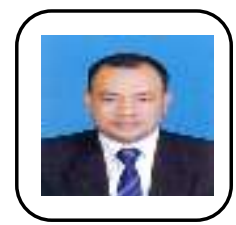

Mahadi Bin Kadir, received his early education in Kelantan and continued his studies in Higher National Diploma in Electrical and Electronic Engineering at the British Malaysian Institute, Kuala Lumpur in partnership with Wigan And Leigh College. He furthered his bachelor degree in Bachelor of Electrical Engineering degree with honors at Universiti Tun Hussein Onn Malaysia (UTHM). Currently, he is attending bachelor's degree in Master of Vocational and Technical Education (TVET) at Universiti Tun Hussein Onn Malaysia (UTHM). He is also a member of the Board of Engineer Malaysia (BEM) and Malaysian Institute of Technology (MBOT). He has a Vocational Training Certificate (VTO) approval by Advanced Training and Skills Training Center (CIAST). He directly involved with SKM Certification as Appraisal Officer, Internal Assessment Officer and External Assessor Officer. He experienced as inspector panel for Certificate of Competency Energy Commission (ST) Phase Three Wireman Competence with Endorsement Testing (PW4). Before joining Majlis Amanah Rakyat (MARA), he worked at several industrial companies such as Hitachi Electronic Products (M) Sdn. Bhd., SMK Electronics (M) Sdn Bhd, Beranang, Selangor. Bhd, Bandar Baru Bangi, Selangor. He recently works as a lecturer at Majlis Amanah Rakyat (MARA) from 2000 till present. He experienced in teaching A1 Certificate of Electrical Engineering Technology (Power) A1, Diploma of Electrical Compensation (A4 Machinery Guardian) and Diploma in Technology Engineering (Domestic and Industrial). Currently, he holds the position of Head of the Diploma of Electrical Competency (Chargeman A4) Program at the Institute Kemahiran MARA Kuala Lumpur.

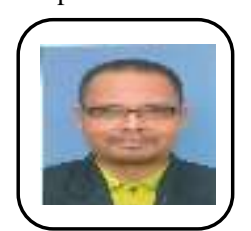

Zulisham Bin Abd Hamid, received a Bachelor of Electrical Engineering degree with honors at Universiti Tun Hussein Onn, Malaysia (UTHM), Diploma in Electrical and Appliance Equipment, Universiti Kuala Lumpur (UniKL) and Diploma in Skills Malaysia (Department of Skills
Development). He was a member of Board of Engineer Malaysia (BEM) and received Vocational Training Certificate (VTO) approval by Advanced Training and Skills Training Center (CIAST). He also directly involved with SKM Certification as Appraisal Officer, Internal Assessment Officer and External Assessor Officer. He experienced as inspector panel for Certificate of Competency of Malaysian Energy Commission (ST). of Electrical Machinery Guardian (Chargeman) and (Wireman) category PW2, PW4, AO, A1 and A4. Before joining Majlis Amanah Rakyat (MARA), he worked at several industrial companies such as Malaysian Mosaics Bhd, Geocera Tiles Sdn Bhd and the Johor Education Foundation. Currently, he was a lecturer at Majlis Amanah Rakyat (MARA) from 2002 till present. He experienced in teaching Prime Programs and Lifetime Programs such as A1 Certificate of Electrical Engineering Technology (Power) A1, Diploma of Electrical Compensation (A4 Machinery Guardian) and Diploma in Technology Engineering (Domestic and Industrial). 